\title{
Employers and the Implementation of Active Labor Market Policies
}

\section{Thomas Bredgaard}

Associate Professor, PhD, Department of Political Science, Aalborg University, Denmark ${ }^{1}$

\section{Jon Lystlund Halkjær}

Head of Section, Ministry of Employment, Denmark

\begin{abstract}
Active labor market policies (ALMPs) are an important instrument for governments in dealing with the new challenges of globalization, flexibilization, and individualization of labor markets. Politics and research has focused on the supply-side of the labor market, that is, regulating the rights and obligations of the target groups of ALMPs (mainly unemployed and inactive persons). The role and behavior of employers is under-researched and under-theorized in the vast literature on ALMPs and industrial relations. In this article, we analyze ALMPs from the employers' perspective by examining the determinants of firms' participation in providing wage subsidy jobs for the unemployed. First, we examine the historical background to the introduction and development of wage subsidy schemes as an important ALMP instrument in Denmark. Second, we derive theoretical arguments and hypotheses about employers' participation in ALMPs from selected theories. Third, we use data from a survey of Danish firms conducted in 2013 to characterize the firms that are engaged in implementing wage subsidy jobs and hypotheses are tested using a binary logistical regression to establish why firms voluntarily engage in reintegrating unemployed back into the labor market. We find that the firms which are most likely to participate in the wage subsidy scheme are characterized by many unskilled workers, a higher coverage of collective agreements, a deteriorating economic situation, a Danish ownership structure, and are especially found in the public sector. This shows that the preference formation of firms is more complex than scholars often assume.
\end{abstract}

\section{KEY WORDS}

Active labor market policies / firms, wage subsidy / implementation

DOI

10.19154/njwls.v6il.4909

\section{Introduction}

eeting the challenges of the globalization of trade and the increasing importance of knowledge in production, firms have adapted their production practices and utilization of labor in the production function (Barr, 2001, p. 169). This has led scholars to point to a decline in the price of low-skilled labor as a result of both the high- and medium-skill bias of the technological process and the massive increase

\footnotetext{
${ }^{1}$ E-mail: thomas@dps.aau.dk
} 
in the supply of low-skilled labor following the emergence of global labor markets (Berthold, 1997; Acemoglu, 2002; Standing, 2009). These developments have significantly increased the unemployment risks of low-skilled labor (Bonoli, 2010). Faced with economic circumstances characterized by "permanent austerity" due to a shift from manufacturing to services (Iversen \& Wren, 1998; Pierson, 2001), nations have moved away from "decommodifying" social transfers and found novel ways of meeting social risks of long-term unemployment. A solution to this came in the form of ALMPs (Crouch et al., 1999).

European countries have, according to their national institutions and political coalitions, adopted ALMPs in different ways (Iversen, 2005, ch. 6; Bonoli, 2010). However, one element is salient; that there is a need to involve employers and employer organizations in the policy process in order to make ALMP effective and responsive to the demands of the labor market (Martin, 2000; Martin \& Swank, 2012). Despite their importance, we nevertheless lack evidence on why and how employers participate in the delivery of ALMPs. This is probably due to the fact that ALMPs tend to focus on the "supply-side" of the labor market and aim at improving the motivation and qualifications of jobseekers and the unemployed. The demand-side is taken-for-granted and not explicitly addressed in policy design or implementation (cf. Ingold \& Stuart, 2015; Aa \& Berkel, 2014).The article is structured as follows: The first section presents the historical background of the policy program analyzed in this article, the Danish wage subsidy jobs scheme (løntilskud). Focus will be on the political decisions and reforms that made this scheme one of the main instrument in Danish ALMP. In the second section, a number of different theories of employers' participation in social and welfare policies (e.g., ALMPs) are described and empirical hypotheses are derived. The third section describes the data and methods. The fourth section presents the empirical findings and the last section discusses the results and presents the conclusion.

\section{Employers and Danish ALMPs}

Denmark has been a frontrunner in the development of ALMP and the engagement of employers in the governance of labor market policies (Auer, 2000; Schmid \& Gazier, 2002). However, in the last decade, the "macro-corporatist" tradition of involving employers' associations and trade unions in the implementation of ALMPs has been somewhat weakened. This was mainly due to the introduction of a new governance structure of local job centers in municipalities from 2007. Local job centers became responsible for the implementation of ALMPs with delegated authority from the central government. In this process, the role of the social partners in the formulation and administration of employment services was marginalized (Bredgaard, 2011). However, policy-makers and local job centers are struggling to engage employers in the recruitment of unemployed jobseekers and to participate in the delivery of ALMP programs at the workplace level. This mixed trend makes it interesting to study empirically how employers actually engage in ALMPs.

Previous comparative studies indicate that Danish employers participate actively in ALMP compared with British and German employers (cf. Martin, 2004; Martin \& Swank, 2012; Nelson, 2013). In the early 2000s, Martin (2004b, p. 130) found that $68 \%$ of Danish employers participated in ALMPs compared with $40 \%$ in the UK. 
Comparing Denmark and Germany, Nelson (2013, p. 40) found that although roughly the same percentage of firms participated in ALMPs, the participation of Danish firms was much more intense than in German firms. In a more recent survey of employer engagement in Denmark and the UK, Ingold and Valizade (2015) found almost similar levels of employer participation in general, but that participation in "funded programs" (like wage subsidy, young person apprenticeships, or one-off and on-going payments) was much higher in Denmark $(50 \%)$ than in the UK $(16 \%)$.

In the current study, we use the participation of employers in the wage subsidy scheme as an indicator of participation in ALMPs. The wage subsidy scheme was introduced for long-term unemployed in 1978 (arbejdstilbudsordningen). The wage subsidy scheme was the first example of an ALMP-instrument in Denmark. The official objective was to improve employment opportunities of participants, but due to the severe unemployment crisis in the late 1970s and 1980s, the scheme in reality became oriented toward avoiding the expiration of unemployment benefit insurance for long-term unemployed. When unemployment benefits expired, the long-term unemployed were offered a "suitable job" for up to 9 months, which gave them a right to another $2 \frac{1}{2}$ years of unemployment insurance. In practice, this meant that the unemployment benefit period could be extended indefinitely and no one would fall out of the unemployment benefit system.

In the late 1980s and early 1990s, the wage subsidy scheme was reformed to improve the employment opportunities of participants. First, rights to formal education and training programs for up to $1 \frac{1}{2}$ years were introduced in 1987 (cf. Rosdahl, 2003). Second, the right to a new period on unemployment insurance benefits after participation in a wage subsidy program was abolished in 1993. This meant that the objective of participation changed from regaining rights to unemployment insurance benefits to improving the employment opportunities and qualifications of participants. At the same time, the duration of the unemployment benefit period was reduced in from 7 years to 5 years in 1995 , then 4 years in 1998, and finally 2 years in 2010. Additionally, a new scheme (individual job training) was adopted for "disadvantaged" unemployed on social assistance who had difficulties in finding ordinary employment. In 2000, a supplementary scheme was introduced where unemployed could participate in short-term training in local firms (arbejdspraktik, later named virksombedspraktik). Participants in this type of company internship (virksombedspraktik) do not receive wages or follow collective agreements, but stay on their former income benefits (unemployment insurance or social assistance).

Currently, the duration of the wage subsidy is up to 6 months. In the public sector, the wage level is equal to the benefit level. In the private sector, the wage level is equal to the wage level of the prevailing collective agreement (the employer tops up from approximately net benefit level to agreed wage). The wage subsidy scheme is mainly used for unemployed persons with a certain level of skills and qualifications, for instance persons on unemployment insurance benefits, who are considered closer to the ordinary labor market than persons on social assistance. The participation of employers in the wage subsidy scheme is, therefore, an indicator of the engagement of employers with ALMPs. We consider it to be a good indicator, since it is one of the most used and effective instruments in Danish ALMPs and requires a deeper level of involvement of employers than other instruments.

In Fig. 1, we illustrate how participants in ALMPs in Denmark are distributed on the three main ALMP instruments: (1) Guidance and education, (2) wage subsidies (løntilskud), and (3) company internships (virksombedspraktik). 
Figure I: Participation in active labor market policies, 2007-2014 (full-time participants).

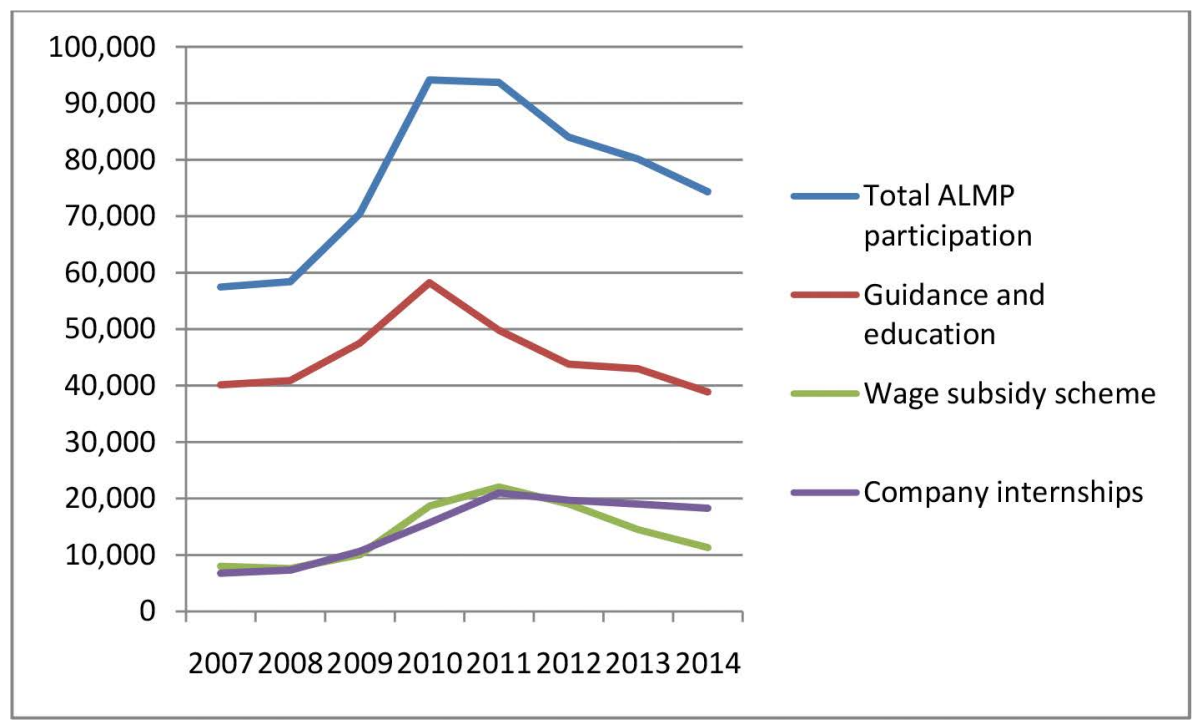

Source: Jobindsats.dk; own calculations.

There are two observations to make. First, the global financial crisis from late 2008 led to a sharp increase in all the three ALMP instruments. Second, participation in ALMP declined after 2011 especially in "guidance and education," while participation in enterprise apprenticeships and wage subsidies remained constant or only slightly declined. "Guidance and education" is an administrative category including a diverse range of different programs, such as municipal counseling and training courses for the "least employable," job search assistance provided by private providers as well as shorter training courses and formal education programs. After a number of negative media reports, the politicians in 2011 decided to get rid of so-called "meaningless activation programs" (especially job search assistance with private providers and municipal counseling and training programs). The central mechanisms for refunding the expenditures of ALMPs in local municipalities were changed so that wage subsidies and company internships received a higher refunding from the central government than "guidance and education" programs.

To sum up, successful ALMPs require engaged employers who are willing to recruit unemployed persons or participate in the delivery of ALMP programs. This basic argument is increasingly acknowledged by Danish policy-makers. Turning to the employers, we now consider what motivates them to participate in the delivery of ALMPs.

\section{Theories of employer engagement in ALMP}

In the literature, there are a number of relevant theoretical starting points for a discussion of employers' participation in the implementation of ALMPs. From a general review of the literature, we have derived six possible explanations for employers' participation in ALMP (cf. Tab. 1). 
Table I Why do employers participate in the implementation of ALMPs?

\begin{tabular}{ll}
\hline Theory & Argument \\
\hline Neo-classic economic theory & $\begin{array}{l}\text { Employers will participate if it serves the short-term economic } \\
\text { interests of the company (Friedman, 1962), for instance if participa- } \\
\text { tion reduces the total labor costs of the company (Ibsen, 1999). }\end{array}$ \\
\hline Theory of collective action & $\begin{array}{l}\text { Employers will participate if participation produces "selective } \\
\text { incentives" for the employers (Olson, I97I), for instance if services } \\
\text { are exclusive to participants (e.g., judicial guidance or recruitment } \\
\text { assistance). }\end{array}$ \\
\hline Power resource theory & $\begin{array}{l}\text { Employers will participate if trade unions possess enough power- } \\
\text { resources to coerce or extort employers to participate in social }\end{array}$ \\
& $\begin{array}{l}\text { policies, thereby making them consenters rather than antagonists } \\
\text { (Korpi, 2006). }\end{array}$ \\
\hline Varieties of capitalism & $\begin{array}{l}\text { Employers will participate if the public policies guard against the } \\
\text { risk of investment in asset-specific skills. By reducing unemployment } \\
\text { risks for workers with asset-specific skills, ALMPs may provide } \\
\text { employers with the type of firm- and industry-specific skills they } \\
\text { require to remain competitive leading them to support these } \\
\text { policies (Hall \& Soskice, 200 I). }\end{array}$ \\
\hline $\begin{array}{l}\text { Employers will participate if peak employer associations join in } \\
\text { the governance and delivery of collective policies, like social } \\
\text { policies and ALMP and membership of employers association in } \\
\text { turn promote the engagement of individual employers in ALMPs } \\
\text { (Martin, 2004, 2005; Martin \& Swank, 20 I 2). }\end{array}$ \\
$\begin{array}{l}\text { Employers will participate if they consider it to be the "right } \\
\text { thing to do" for ethical or moral reasons (Aa \& Berkel, 20 I 4; } \\
\text { Bredgaard, 20 I4). }\end{array}$ \\
\hline CSR theory \\
\end{tabular}

The theories can be categorized in a number of different ways. Some are macrotheories from which we can deduce hypothesis about how the institutional framework and political economy make it more or less likely that firms participate in social and welfare policies (e.g., varieties of capitalism, power resource theory, and institutional theory). Others are micro-theories that may explain why individual employers choose to participate or refrain from participating in specific ALMP-instruments (e.g., neoclassic economic theory and the theory of collective action). Some theories argue that employers participate from altruistic reasons (CSR-theory), while others argue that they participate for economic reasons (neo-classic economic theory) or legitimatory reasons (e.g., institutional theory).

In the following, we have operationalized the power resource theory, Varieties of Capitalism, and neo-classical economic theory. This choice is a function of the limitations of the survey. For example, testing institutional theory can be done by distinguishing between whether or not a firm is a member of an employer association (Martin \& Swank, 2012). The available empirical studies of the association between membership of employers' associations and employers' engagement in ALMPs are inconclusive. Martin 
(2005) found that membership of national employers' associations in Denmark was a highly salient positive determinant of participation in social programs, while Ingold and Valizade (2015) did not find a direct link between the two. Instead, they found a positive association between collective bargaining coverage and employers' engagement in ALMPs, and suggest that collective bargaining may be an in important mediating variable. We cannot test the argument from CSR theory either due to insufficient survey data, but do know from previous research that one of the most important justifications of employers for participating in ALMP programs is their sense of social responsibility (Jakobsen et al., 2015).

\section{Hypothesis of the study}

From this short introduction to theories of employers' participation in ALPMs, we will derive a number of specific hypotheses to inform the empirical study of the participation of Danish employers in the wage subsidy scheme in Table 2.

Table II Hypothesized determinants for the participation of firms in ALMP

\begin{tabular}{|c|c|c|}
\hline Hypothesis I & Skill-level & $\begin{array}{l}\text { Firms using specific skills are more likely to } \\
\text { participate than firms using general skills. }\end{array}$ \\
\hline Hypothesis 2 & Sector & $\begin{array}{l}\text { Firms in the service sector are less likely to } \\
\text { participate than firms in the industry. }\end{array}$ \\
\hline Hypothesis 3 & Collective Agreement coverage & $\begin{array}{l}\text { Firms that covered higher coverage of collective } \\
\text { agreements are more likely to participate than } \\
\text { firms with lower coverage. }\end{array}$ \\
\hline Hypothesis 4 & Economic situation of the firm & $\begin{array}{l}\text { Firms where the economic situation has worsened } \\
\text { within the last few years are more likely to partici- } \\
\text { pate than firms where the economic situation has } \\
\text { improved in the last few years. }\end{array}$ \\
\hline Hypothesis 5 & Internationalization of the firm & $\begin{array}{l}\text { Firms with a primarily Danish ownership structure } \\
\text { and firms that sell their products primarily on the } \\
\text { national market are more likely to participate than } \\
\text { firms owned primarily by foreign actors or selling } \\
\text { their products on the international market }\end{array}$ \\
\hline
\end{tabular}

\section{Hypothesis I. Skill-level}

Within the VoC framework, ALMPs do not count as one of the main social institutions supporting the formation of a certain skill profile in firms. However, reading the literature on ALMP, these policies can function as "Employment Security" by quickly reintegrating the unemployed back into the labor market and reducing unemployment spells (Schmid, 1995; Madsen, 2011). As such, ALMP can in line with the VoC framework function as a social insurance against unemployment, thus reducing the uncertainty and collective problems associated with investing in specific skills. In line with this conception, the skill composition of the work force can be expected to have the following 
effect: By shortening the unemployment spells, ALMPs can protect skilled wages thereby reducing the uncertainty associated with investing in industry and firm specific skills (Estevez-Abe et al., 2001, pp. 152-153). This thesis is operationalized as follows; if the firm has a majority of either skilled blue-collar workers or skilled white-collar workers, it will have an incentive to take part in implementing the wage subsidy scheme. Conversely, if the firm has a majority of workers with general skills, it will have an incentive not to take part in implementing wage subsidy schemes.

\section{Hypothesis 2. Sector}

The sector in which the firm is situated is likewise within the VoC literature held out as a significant determinant for the preferences of firms. Whereas industry broadly understood utilizes specific skills, general skills as well as more theoretical knowledge are more important in the service sector (Busemeyer \& Trampusch, 2012, p. 28). These skill requirements of the sectors are expected to have a strong influence on the preference held by firms. The thesis is hypothesized as follows; the level of willingness of firms to implement the wage subsidy schemes will be a function of the sector within which they operate. Sector will be operationalized as public sector, the private service sector, or industry.

\section{Hypothesis 3. Collective agreement coverage}

The power resources theories put an emphasis on the power resources of labor when seeking to account for both macro-level outputs such as redistribution (Korpi \& Shalev, 1979; Esping-Andersen, 1990; Huber \& Stephens, 2001) and micro-level outputs such as the preferences for social institutions held by firms (Streeck \& Schmitter, 1999). The level of collective bargaining coverage at the company level is thus a key explanatory variable influencing the involvement of firms in the implementation of wage subsidy schemes. Following Streeck and Schmitter (1999), employers will always prefer to avoid any involvement in social institutions of any kind. However, the presence of unions at the firm level can through "the logic of influence" force the employers to get involved in a social agenda, such as the implementation of job-placement schemes. This thesis is hypothesized as follows; the willingness displayed by firms in relation to implementing the wage subsidy schemes will be a function of the share of employees at a firm covered by a collective agreement.

Economic theories put critical emphasis on the role of economic characteristics as determinants for the preferences held by firms for ALMP. On the basis of the underlying "efficiency thesis" whereby increased competition forces firms to increase their competitiveness by making the factors of production (labor, land, and money) more flexible, we can point to two additional variables that can be expected to influence the involvement of firms in the implementation of wage subsidy schemes: the economic situation of the firm and the internationalization of the firm.

\section{Hypothesis 4. Economic situation of the firm}

The economic situation of the firm can be expected to have the following effect on the dependent variable; worsened economic situation for the firm can lead it to participate 
in the wage subsidy scheme in order to gain access to subsidized and cheap labor (Ibsen, 1999). This thesis is hypothesized as follows; the willingness of firms in relation to implementing the wage subsidy scheme will be a function of the economic situation of the firm.

\section{Hypothesis 5. Internationalization of the firm}

Economists have argued that the globalization of markets have necessitated firms to shed themselves from social costs (Strange, 1996, pp. 59-65). Thus, the degree of internationalization experienced by the firm can be expected to influence to what degree the firm is willing to take on a social cost like implementing the wage subsidy scheme. This thesis is hypothesized as follows; the willingness to actively engage in implementing the wage subsidy scheme will be a function of the internationalization of the firm. The internationalization of the firm is operationalized along two independent variables. The firms are asked if the primary markets of the firm is either national or international. Second, the firms are asked if they are primarily national or international in their ownership structure.

\section{Research Design, Data, and Methods}

We use survey data that have been collected by Statistics Denmark among a representative sample of Danish companies with more than five employees in the autumn of 2013. Four thousand five hundred workplaces were contacted and 1499 workplaces completed the questionnaire (response rate $=33 \%$ ). The respondents were the persons making decisions on personnel management (e.g., HRM manager, owner, or director). The data were then weighted by industry and the number of employees in order to ensure that the sample was representative for the population of Danish companies. The dependent variable chosen for this study is a question that seeks to survey the involvement of a firm in implementing the wage subsidy scheme: "Does the firm currently have one or more people employed in wage subsidies?" The response category is dichotomous in the form of a "yes" and "no" category.

Besides effectively surveying the involvement of firms, wage subsidies were chosen because the distribution of cases is fairly even; 39\% answered yes and $61 \%$ answered no. Seeing as the dependent variable is binary or dichotomous, the statistical model used must be a logistic regression as opposed to a linear regression, which is most fitting if the dependent variable is continuous (Hosmer \& Lemeshow, 2013, ch. 1.1). The method by which we will test our hypothesis regarding what determinants can explain the involvement of firms in the implementation of wage subsidies is the binary logistical regression model. As a way of testing the correlation, we will do this through odds ratio and Nagelkerke. Nagelkerke shows the strength of the correlation in much the same way as R Square does (Nagelkerke, 1991). Odds ratio allows us to evaluate the likeliness of a certain outcome among respondent X as compared with respondent Y (Hosmer \& Lemeshow, 2013, ch. 3.2).

\section{Empirical results}

We have analyzed these determinants on the basis of the hypotheses presented earlier in Table 3.

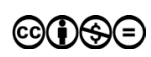


Table III Characteristics of firms engaging in the implementation of job-placement schemes, binary logistic regression (odds ratio)

\begin{tabular}{cl}
\hline Skill composition of the work force & \\
$0 \%$ unskilled & Baseline \\
$1-20 \%$ unskilled & $1.85 I^{* * *}$ \\
$21-40 \%$ unskilled & $1.963^{*}$ \\
$4 I-60 \%$ unskilled & $1.770^{*}$ \\
\hline $0-20 \%$ MSc. grads. & Baseline \\
$21-40 \%$ MSc. grads. & $0.408^{*}$ \\
$61-80 \%$ MSc. grads. & $0.358^{*}$ \\
$81-100 \%$ MSc. grads. & $0.368^{*}$ \\
\hline
\end{tabular}

Sector

Construction Baseline

$\begin{array}{ll}\text { Public Sector } & \text { 2.561*** }\end{array}$

Share of employees in the firm working under a collective agreement

$50 \%$ or less Baseline

More than $51 \%$
$1.976 * * * * 1 \%$

Economic situation of the firm within the last few years

Worsened Baseline

Improved 0.679*

Primary ownership of the firm

International Baseline

National 1.943*

$\mathbf{N}(\%$ of total $\mathbf{N}) \quad$ |46। (97.5)

Hosmer \& Lemeshow goodness of fit $\quad 0.090$

$\begin{array}{ll}\text { Nagelkerke } & 0.291\end{array}$

Note: Binary logistical regression (Does the firm currently have one or several people employed in job-placement schemes? $(0=$ no, I = yes). P-value: $* * * * 0.001$; $* *<0.0$ I; $* 0.05$.

The variables that proved insignificant in the regressions have been omitted in the table above. The regressions were conducted in three stages, where a new set of theoretically deduced variables were included at each stage. This allows the research to better evaluate if the variables are susceptible to interaction effects from other variables. A separate regression involving only the economic determinants was conducted (sector and size was controlled for), which give $0.646^{*}$ and $1.963^{*}$. A regression was also conducted where the Public Sector was omitted. This shows the exact same independent variables to be significant and strong. Due to this, the public sector is included in the table above to increase the overall $N$. As we can see from the Nagelkerke value in the bottom of the table, $29.1 \%$ of the variance in the firms' response to the question: "Does the company currently have one or several people employed in job-placement schemes?" can be explained by the omitted determinants and their derived variables.

Initially, the regressions conducted show that most of the sector variables are insignificant. Of the nine different industries belonging to either the service sector, industry, or the public sector, the only sector where the effect is significant is that of the 
public sector. Compared with the baseline (construction), firms in the public sector had $2.561 * *$ higher odds of being engaged in implementing wage subsidy schemes, than firms in the construction sector.

The skill composition of employees holds a central position within the VoC framework. However, the empirical evidence does not confirm this as an explanatory variable. The regression analysis shows that as the share of unskilled workers in a firm increases, the odds that the firm will employ an unemployed through a wage subsidy scheme decreases from $1.851 *$ for firms with $1-20 \%$ unskilled to $1.770 *$ for firms with $40-60 \%$ unskilled. Furthermore, we also find significant effects from the variable showing the share of employed with MSc. degrees at the firm. Here, the regression show that as the share of workers with MSc. degrees increases from between $21-40 \%$ to $61-80 \%$ and $81-100 \%$, the odds that the firm will engage in implementing the wage subsidy scheme decreases in the third column from $0.408^{*}$ to $0.358^{*}$ and $0.368^{*}$. These results partly confirm the hypotheses on the effect of the skill composition. As the share of workers with general skills increase, the willingness of the firm to engage in the implementation of ALMP decreases. However, the regression analysis does not show the opposite to be true. The regression does not show that as the share of workers with specific skills increases, so does the willingness to engage in the implementation of ALMP. Therefore, despite occupying a central place in the VoC framework, skill composition of the work force seems a weaker explanation of firms' participation in ALMP. This merits further academic analyses of this particular correlation.

The share of employees covered by collective agreements is also found to be important for participation in wage subsidy schemes. We find that firms where more than $51 \%$ are covered by collective agreements have $1.976 * * *$ times higher odds of being involved in the implementation of the wage subsidy scheme than in firms where less than $50 \%$ are covered by collective agreements.

The economic situation of the firm and the nationality of the primary ownership have explanatory power as well. If we initially turn to the role played by the economic situation of the firm, we find that the hypothesis holds. Using firms where the economic situation within the last few years have worsened as baseline, we find that firms where the economic situation has improved within the last few years have $0.679 *$ times lower odds of implementing the wage subsidy scheme than the baseline category. Turning to the next variable, we find that the nationality of the actors controlling the main part of the firm has a strong impact. Firms primarily owned by Danish actors have $1.943 *$ times higher odds than the firms primarily owned by foreign actors to participate in wage subsidies. The data thus seem to confirm the existence of the globalization v. ALMP dilemma; globalization necessitates ALMP and the engagement of employers in ALMP, but it also drives the firms to make their activities more efficient and shed themselves of social responsibilities that are not considered to contribute to the economic performance of the company. The establishment of this dilemma falls much in line with scholarly literature on the effects of globalization (McKenzie \& Lee, 1991; Strange, 1996).

\section{Conclusion}

Active participation of employers in the integration of unemployed in the labor market is crucial for the effectiveness of ALMPs. But the literature as well as policies of ALMPs 
have tended to neglect the role of employers and instead focused on the "supply-side" of the labor market. Denmark is considered a "best case" of employers' engagement in the implementation of ALMPs. Comparative studies indicate that in general, Danish employers are more likely to participate actively in the delivery of ALMPs than employers in other comparable countries, for example, the UK and Germany.

Nevertheless, even in Denmark, a large proportion of firms do not participate in the delivery of ALMPs. So, why do some employers participate in the delivery of ALMPs, while others do not participate. In the literature, there are six promising candidates for a theoretical grounding of the motivations of employers to participate in ALMPs: Neoclassic economic theory, the theory of collective action, power resource theory, varieties of capitalism, institutional theory, and CSR theory. Each of these theories can be used to formulate specific empirical hypotheses about firms' participation in ALMPs, and in this case the wage subsidy scheme. The wage subsidy scheme is the first example of an ALMP instrument in Denmark and requires a deeper level of commitment of employers than other instruments. It is also the most effective instrument in the ALMP toolbox, especially when applied in the private sector.

The empirical results of this study show that the participation of employers in the Danish wage subsidy scheme is determined by a number of different variables. First, the empirical analysis showed that employers with a higher proportion of unskilled workers or a lower proportion of graduates were more likely to use the wage subsidy scheme. This finding may be explained by the fact that the majority of unemployed who participate in the wage subsidy scheme are in fact unskilled or low-skilled, thereby providing employers with an improved base for recruitment. Second, the proportion of employees covered by collective agreements was also found to correlate with participation in the wage subsidy scheme, so that firms with a higher coverage of collective agreements were more likely to participate. Third, firms where the economic situation had worsened within the last years were more likely to participate in the wage subsidy scheme. The empirical evidence thus indicates that firms may use subsidized labor as a means of coping with economic hardship leading to distortion of competition and crowding out. Finally, we found that the sector and nationality of the firm could also explain participation in the wage subsidy scheme. The analysis confirmed previous research that employers in the public sector and firms owned by Danish actors were more likely to participate in ALMPs than employers in the private sector and firms owned by international actors.

The analysis clearly shows that firms are not only the means-end calculating entities but they are also often assumed to be in both economic theory and public choice theories. Their preferences for ALMP, in general, and wage subsidy schemes, in particular, cannot be explained solely with reference to their economic characteristics alone. These findings fall in line with previous analyses on the preferences of Danish firms for flexicurity (Author \& Author, 2015).

The role of employers in the delivery of ALMPs is still a new and emerging field of research. We have taken the first steps toward a theoretically informed empirical analysis of employers' participation in ALMP. The research should be pursued further by comparative data to measure national differences in employers' engagement and historical data to compare temporal changes in employers' engagement in social and labor market policies. The empirical analysis would also benefit from more detailed qualitative studies of the preference formation of employers and actual implementation processes at the 
company level. Considering the centrality of employers in implementing ALMPs, these are important topics for future research.

\section{References}

Aa, P. \& R. Berkel (2014) Innovating job activation by involving employers, International Social Security Review 67(2): 11-27. doi: http://dx.doi.org/10.1111/issr.12036.

Auer, P. (2000) Employment revival in Europe - Labour market success in Austria, Denmark, Ireland and the Netherlands, Geneva: International Labour Office.

Acemoglu, D. (2002) Technical change, inequality, and the labour market, Journal of Economic Literature 40(1): 7-72. doi: http://dx.doi.org/10.3386/w7800.

Barr, N. (2001) The Welfare State as Piggy Bank, Oxford: Oxford University Press.

Berthold, N. (1997) Arbeitslosigkeit oder Einkommensungkeichheit - Fluch globaler Märkte?, Politische Studien 43(352): 36-57.

Bonoli, G. (2010) The political economy of active labor-market policy, Politics and Society 38(4): 435-457. doi: http://dx.doi.org/10.1177/0032329210381235.

Busemeyer, M. \& Trampusch, C. (2012) The Comparative Political Economy of Collective Skill Formation. In Busemeyer, M. R. \& Trampusch, C. (eds.) The Political Economy of Collective Skill Formation, Oxford: Oxford University Press, pp. 3-40.

Crouch, C., Finegold, D. \& Sako, M. (1999) Are Skills the Answer. The Political Economy of Skills Creation in Advanced Industrial Countries, Oxford: Oxford University Press.

Esping-Andersen, G. (1990) Three Worlds of Welfare Capitalism, Cambridge: Princeton University Press.

Estevez-Abe, M., Iversen, T. \& Soskice, D. (2001) Social Protection and the Formation of Skills: A Reinterpretation of the Welfare State. In Hall, P. A. \& Soskice, D. (eds.) Varieties of Capitalism. The Institutional Foundation of Comparative Advantage, Oxford: Oxford University Press, pp. 145-183.

Friedman, M. (1962) Capitalism and Freedom (3. ed. 2002), Chicago: University of Chicago Press.

Hall, P. A. \& Soskice, D. (2001) An Introduction to Varieties of Capitalism. In Hall, P. A. \& Soskice, D. (eds.) Varieties of Capitalism. The Institutional Foundation of Comparative Advantage, Oxford: Oxford University Press, pp. 1-70.

Huber, E. \& Stephens, J. (2001) Development and Crisis of the Welfare State: Parties and Policies in Global Markets, Chicago: Chicago University Press.

Ibsen, F. (1999) Er det rationelt for virksomhederne at påtage sig et socialt ansvar? [Is corporate social responsibility rational for companies?], Tidsskrift for Arbejdsliv 1(2): 35-45.

Ingold, J. \& Valizade, D. (2015) Employer engagement in active labour market policies in the UK and Denmark: a survey of employers, Policy report no. 6, Centre for Employment Relations, Innovation and change (CERIC), Leeds University Business School.

Iversen, T. \& Wren, A. (1998) Equality, employment, and budgetary restraint: the trilemma of the service economy, World Politics 50(4): 507-546. doi: http://dx.doi.org/10.1017/ $\underline{\text { S0043887100007358. }}$.

Iversen, T. M. (2005) Capitalism, Democracy and Welfare, New York: Cambridge University Press.

Jakobsen, V., Larsen, M. \& Jensen, S. (2015) Virksombedernes sociale engagement - årbog 2015 [Corporate social responsibility - yearbook 2015], Copenhagen: SFI - Det Nationale Forskningscenter for Velfærd.

Jørgensen, H. (ed.) (2002) Cooperation, Consensus and Conflict, Edward Elgar Publishing.

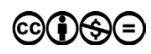


Korpi, W. \& Shalev, M. (1979) Strikes, industrial relations and class conflict in capitalist societies, British Journal of Sociology 30: 164-187. doi: http://dx.doi.org/10.2307/589523.

Korpi, W. (2006) Power resources and employer-centred approaches in explanations of welfare states and varieties of capitalism: Protagonists, consenters, and antagonists, World Politics 58(2): 167-206. doi: http://dx.doi.org/10.1353/wp.2006.0026.

Madsen, P. K. (2011) Flexicurity og det danske arbejdsmarked. In Bredgaard, T., Jørgensen, H., Madsen, P. K. \& Rasmussen, S. (eds.) Dansk Arbejdsmarkedspolitik (Danish Labour Market policy), Copenhagen: DJØF Forlag, pp. 29-43.

Martin, J. (2000) What works among active labour market policies, OECD Economic Studies 30(1): 79-113. doi: http://dx.doi.org/10.1787/eco studies-v2000-1-en.

Martin, C. J. (2004) Reinventing welfare regimes: employers and the implementation of active social policy, World Politics 57(1): 39-69. doi: http://dx.doi.org/10.1353/wp.2005.0012.

Martin, C. J. (2005) Corporatism from the firm perspective: employers and social policy in Denmark and Britain, British Journal of Political Science 35(1): 127-148. doi: http://dx.doi.org/10.1017/S0007123405000062.

Martin, C. J. \& Swank, D. (2012) The Political Construction of Business Interests: Coordination, Growth and Equality, New York: Cambridge University Press.

McKenzie, R. \& Lee, D. (1991) Quicksilver Capital: How the Rapid Movement of Wealth Has Changed the World, New York: Free Press.

Nagelkerke, N. J. D. (1991) A note on a general definition of the coefficient of determination, Biometrika 78(3): 691-692. doi: http://dx.doi.org/10.2307/2337038.

Nelson, M. (2013) Revisiting the role of business in welfare state politics: neocorporatist versus firm-level organisation and their divergent influence on employer support for social policies, Comparative European Politics 11(1): 22-48. doi: http://dx.doi.org/10.1057/cep.2012.16.

Olson, M. (1971) The Logic of Collective Action: Public Goods and the Theory of Groups. Cambridge, MA: Harvard University Press.

Pierson, P. (2001) Coping with Permanent Austerity: Welfare State Restructuring in Affluent Democracies. In Pierson, P. (ed.) The New Politics of the Welfare State, Oxford: Oxford University Press, pp. 410-457.

Rosdahl, A. (2003) Lediges understøttelseperiode. In P.K. Madsen \& Pedersen, L. (eds.) Drivkrefter bag arbejdsmarkedspolitikken (The drivers of labour market policies), Copenhagen: Socialforskningsinstituttet, pp. 100-135.

Rosholm, M. \& Svarer, M. (2011) Effekter af den virksomhedsrettede indsats i den aktive arbejdsmarkedspolitik (Effects of company based activation programs in ALMP), Analyse for Arbejdsmarkedsstyrelsen.

Schmid, G. (1995) Is full employment still possible? Transitional labour markets as a new strategy of labour market policy, Economic and Industrial Democracy 16: 429-456. doi: http://dx.doi.org/10.1177/0143831X95163005.

Schmid, G. \& Gazier, B. (2002) The dynamics of full employment-social integration through transitional labour markets, Cheltenham: Edward Elgar.

Schmitter, P. C. \& Streeck, W. (1999) The Organization of Business Interests. Studying the Associative Action of Business in Advanced Industrial Societies, MPIfG Discussion Paper 99/1.

Standing, G. (2009) Work after Globalization: Building occupational citizenship, Cheltenham: Edward Elgar.

Strange, S. (1996) The Retreat of the State: Diffusion of Power in the World Economy, New York: Cambridge University Press. 